\title{
PENGARUH PROMOSI MEDIA SOSIAL DAN WORD OF MOUTH (WOM) TERHADAP KEPUTUSAN PEMBELIAN KONSUMEN (STUDI DI TOKO BUKU LA TANSA GONTOR)
}

\author{
Mufti Afif, Aulia Fathan Mubin, Ahmad Suminto \\ Universitas Darussalam (UNIDA) Gontor, Indonesia \\ muftiafif@unida.gontor.ac.id, fathanaffan08@gmail.com, \\ ahmadsuminto@unida.gontor.ac.id
}

\begin{abstract}
The purpose of this study was to determine the effect of social media promotion (online) and Word of Mouth (WOM) on consumer purchasing decisions at La Tansa Gontor Bookstore. This research is quantitative research with data sources obtained from primary data in the form of the results of respondents' answers to La Tansa Gontor Bookstore consumers, and secondary data in the form of written information from the web and social media. Questionnaire data was collected using random sampling technique, with an infinite number of populations. The sample used is 300 respondents. The results showed: 1) Social media promotion (online) had a positive and significant effect on consumer purchasing decisions at La Tansa Gontor Bookstore, this was because the social media admin of La Tansa Gontor Bookstore provided good and interesting and responsive information so that it could influence consumers. to make consumer purchasing decisions. 2) Word of Mouth (WOM) has a positive and significant effect on purchasing decisions because consumers are satisfied with the service and product quality offered.
\end{abstract}

Keywords: Promotion, Social Media, Word of Mouth(WOM), Purchase Decision

\begin{abstract}
Abstrak: Tujuan dalam penelitian ini untuk mengetahui pengaruh promosi media sosial (online) dan Word of Mouth (WOM) terhadap keputusan pembelian konsumen Toko Buku La Tansa Gontor. Penelitian ini merupakan penelitian kuantutatif dengan sumber data diperoleh dari data primer berupa hasil jawaban responden konsumen Toko Buku La Tansa Gontor, dan data sekunder yang berupa informasi tertulis dari web dan media sosial. Pengumpulan data angket dilakukan dengan teknik random sampling, jumlah populasi yang tak terhingga. Sampel yang digunakan 300 responden. Hasil penelitian menunjukkan: 1) Promosi media sosial (online) berpengaruh positif dan signifikan terhadap keputusan pembelian konsumen Toko Buku La Tansa Gontor, hal ini disebabkan karena admin media sosial Toko Buku La Tansa Gontor memberikan informasi yang baik dan menarik serta responsif sehingga dapat mempengaruhi konsumen untuk melakukan keputusan pembelian konsumen. 2) Word of Mouth (WOM) berpengaruh positif dan signifikan terhadap keputusan pembelian karena konsumen mnyatakan puas dengan pelayanan dan kualitas produk yang ditawarkan.
\end{abstract}

Kata Kunci: Promosi, Media Sosial, Word of Mouth (WOM), Keputusan Pembelian

\section{PENDAHULUAN}

Keputusan pembelian merupakan tahap dari proses keputusan konsumen yang melakukan tindakan membeli produk yang ditawarkan oleh suatu perusahaan pemasar. Tahapan tersebut timbul dari konsumen yang mengenal masalahnya, yaitu mencari informasi 
JoIE: Journal of Islamic Economics | Mufti Afif, Aulia Fathan Mubin, Ahmad Suminto P-ISSN: 2807-7377

E-ISSN: 2807-7091

mengenai produk atau merek tertentu dan mengevaluasi seberapa baik setiap alternatif yang tersedia sehingga dapat memecahkan masalahnya yang kemudian mengarah kepada keputusan pembelian (Udin, 2020). Mayoritas konsumen membeli barang dan jasa bertujuan untuk memuaskan keinginan dan kebutuhannya. Dalam Islam kebutuhan dan keinginan memiliki perbedaan yang signifikan. Kebutuhan bersifat naluriyah sedangkan keinginan merupakan kebutuhan buatan yaitu kebutuhan yang dibentuk oleh lingkungan hidup (Swastha \& Handoko, 2016).

Keputusan pembelian juga merupakan bagian dari perilaku kosumen. Dapat juga dimaknai sebagai suatu studi tentang bagaimana pembuat keputusan (decision unit), baik individu, kelompok, maupun organisasi membuat keputusan-keputusan beli atau melakukan transaksi pembelian atas sebuah produk dan jasa. (Schiffman \& Prase, 2005) Pemasaran adalah salah satu bentuk muamalah yang dibenarkan dalam Islam, selama proses pemasarannnya harus menjauhi hal-hal yang dilarang oleh ketentuan syariah.

Promosi merupakan salah satu bauran pemasaran (marketing mix). Dalam Islam semua usaha yang dilakukan oleh pengusaha ditujukan untuk meningkatkan kreatifitas dan ide inovatif dalam usahanya untuk menarik minat pelanggan baru dan mempertahankan pelanggan yang sudah ada, maka diperbolehkan melakukan kegiatan promosi (Asnawi, 2017). Seiring berkembangnya zaman, peningkatan teknologi menjadikan salah satu strategi pemasaran yang memudahkan dan membantu menjaring banyak calon konsumen, yaitu melalui media sosial (online). Pemasaran melalui media online ini sering disebut dengan istilah e-marketing, menurut Brenda Kienan bahwa e-marketing adalah bisnis dengan menjual produk atau jasa kepada konsumen secara online. Sederhananya adalah membangun hubungan antara penjual dan pembeli secara online (Endang, 2013).

Selain promosi melalui media sosial, Word of Mouth (WOM) juga merupakan salah satu strategi promosi dalam kegiatan pemasaran, yaitu menggunakan media "orang ke orang" yang memiliki rasa puas untuk meningkatkan kesadaran tentang produk dan menghasilkan tingkat penjualan tertentu. Word of Mouth atau disebut juga dengan komunikasi dari mulut ke mulut menyebar melalui jaringan bisnis, sosial dan masyarakat yang dianggap sangat berpengaruh. (Puspita, 2016) Word of Mouth (WOM) merupakan upaya memberikan orang alasan untuk membicarakan merek, produk, atau layanan dan membuat berlangsungnya percakapan lebih mudah. Perusahaan merangsang minat konsumen dengan mendorong konsumen untuk berbagi pengalaman dengan orang lain. (Hasan A. , 2010) 
JoIE: Journal of Islamic Economics | Mufti Afif, Aulia Fathan Mubin, Ahmad Suminto P-ISSN: 2807-7377

E-ISSN: 2807-7091

Terdapat beberapa penelitian tentang pengaruh promosi media sosial (online) terhadap keputusan pembelian. Diantaranya dilakukan oleh Rizka Imelda dan Erni Martini (2019); Elin Lininati (2018); Muhammad Mas'udin dan Yuliawati (2020); F. Safwa Farook dan Nalin Abeysekara (2016); Bagas Aji dan Siti Zuhroh (2016) hasil penelitian mereka menjelaskan bahwa promosi media sosial memberikan pengaruh yang signifikan terhadap keputusan pembelian karena membantu konsumen dalam mendapat informasi mengenai barang atau produk yang ditawarkan suatu perusahaan atau pembisnis. Selain penelitian tersebut, ada penelitian yang menunjukan promosi media sosial tidak mempengaruhi keputusan pembelian, sebagaimana dilakukan oleh Failatul Khoiro, Rachma, dan M. Hufron (2019). Adapun alasannya adalah adanya variable viral marketing yang lebih berpengaruh secara signifikan dibandingkan promodi melalui media sosial. Selain itu juga terdapat terdapat beberapa penelitian tentang pengaruh Word of Mouth (WOM) terhadap keputusan pembelian.

Di antara penelitian yang dilakukan: Bagas Aji dan Siti Zuhroh (2016); Iknesya Rahma Finanda dan Arjuna Wiwaha (2017); Sheng Chung Lo (2012); serta Muhammad Dian dan Evi Husniati Syaidah (2018) Dari hasil penelitiannya disimpulkan bahwa strategi Word of Mouth (WOM) memberikan pengaruh positif terhadap keputusan pembelian karena pembeli mendapat informasi dari orang yang memiliki pengalaman dan kesan baik terhadap perusahaan atau pembisnis sehingga mampu merekomendasikan kepada orang lain. Berdasarkan uraian di atas peneliti tertarik melakukan penelitian untuk mengetahui seberapa berpengaruh Pengaruh Promosi Media Sosial (Online) dan Word of Mouth (WOM) keputusan pembelian konsumen di Toko Buku La Tansa Gontor. Maka peneliti mengambil judul "Pengaruh Promosi Media Sosial dan Word of Mouth (WOM) terhadap Keputusan Pembelian Konsumen (Studi di Toko Buku La Tansa Gontor)”.

\section{TINJAUAN LITERATUR}

\section{Keputusan Pembelian}

Menurut Schiffman dan Kanuk (2004), keputusan pembelian adalah proses yang dilalui seseorang dalam mencari, memilih, membeli, menggunakan, mengevaluasi dari salah satu dari dua alternatif atau lebih yang ada. Seseorang bisa membuat keputusan jika terdapat banyak alternatif pilihan. Keputusan pembelian dapat mengarah kepada bagaimana proses keputusan tersebut dijalankan. Keputusan pembelian konsumen dipengaruhi oleh perilaku konsumen (Schiffman \& Kanuk, Jakarta). 
JoIE: Journal of Islamic Economics | Mufti Afif, Aulia Fathan Mubin, Ahmad Suminto P-ISSN: 2807-7377

E-ISSN: 2807-7091

Menurut Kotler dan Keller (2008) mendefinisikan Keputusan pembelian merupakan tahap dari proses keputusan konsumen yang melakukan tindakan dalam membeli produk yang ditawarkan. Tahapan tersebut timbul dari konsumen mengenal masalahnya, mencari informasi mengenai produk atau merek tertentu dan mengevaluasi seberapa baik masing-masing alternatif tersebut sehingga dapat memecahkan masalahnya yang kemudian mengarah kepada keputusan pembelian (Udin, 2020).

Menurut Kotler dan Keller (2006) menjelaskan bahwa teori AIDA (Attention, Intrest, Desire, Action) merupakan sesuatu yang harus mendapatkan perhatian, ketertarikan, minat, dan pengambilan tindakan. Teori yang menyampaikan akan kualitas dari informasi yang baik. Berikut adalah penjelasan mengenai teori AIDA (Attention, Intrest, Desire, Action) yang digunakan untuk mengukur keputusan pembelian:

1) Perhatian (Attention). Informasi yang menarik perhatian merupakan langkah awal yang harus dilakukan oleh perusahaan sehingga informasi tersebut dapat dikenal, diketahui dan diingat oleh konsumen.

2) Ketertarikan (Intrest). Tertarik berarti informasi yang disampaikan mengenai barang atau produk menimbulkan perasaan keingintahuan, mengamati, dan mendengar serta melihat. Hal tersebut terjadi karena adanya minat yang menarik perhatian konsumen akan informasi yang diberikan mengenai produk.

3) Keinginan (Desire). Sugesti tersebut terjadi dari adanya keinginan yang berkaitan dengan motif dan motivasi konsumen dalam membeli produk yang ditawarkan. Motif dalam pembelian dibedakan menjadi dua, yaitu: motif rasional dan ekonomi.

4) Tindakan (Action). Terjadi dengan adanya keinginan dan motivasi kuat konsumen sehingga terjadi pengambilan keputusan dalam melakukan pembelian produk yang ditawarkan (Kotler, 2006).

\section{Promosi Media Sosial}

Menurut Alma (2005) promosi adalah jenis komunikasi yang menjelasan dan meyakinkan konsumen tentang barang dan jasa yang ditawarkan. Hal ini bertujuan untuk memperhatikan, memberi informasi, mengingatkan, dan meyakinkan konsumen. (Daud, 2013) Promosi merupakan upaya untuk memperkenalkan dan menawarkan produk kepada konsumen. Dalam Islam melaksanakan promosi dilarang memberikan informasi yang berlebihan. Rasulullah SAW sendiri dalam melakukan promosi barang yang diperdagangkan tidak pernah memberikan informasi yang berlebihan, justru beliau memberikan informasi apa 
JoIE: Journal of Islamic Economics | Mufti Afif, Aulia Fathan Mubin, Ahmad Suminto P-ISSN: 2807-7377

E-ISSN: 2807-7091

adanya sehingga pembeli memperoleh informasi tentang produk secara jelas sebelum memutuskan untuk membelinya (Asnawi, 2017).

Pada zaman dahulu informasi hanya bisa didapatkan melalui surat kabar, koran, dan radio. Dengan semakin berkembangnya teknologi informasi dapat didapatkan melalui banyak sumber serta mudah dijangkau oleh semua golongan. Salah satunya menggunakan internet dan media sosial. Hal inilah yang mendorong para pembisnis untuk melakukan pemasaran produk serta jasa dengan menggunakan perantara tersebut.

Media sosial adalah hubungan sosial yang dibantu dengan media online. Teknologi yang digunakan media sosial adalah berbasis web sehingga menciptakan dialog interaktif antar penggunanya. Media sosial juga didefinisikan sebagai lingkungan online tempat orangorang dengan minat yang sama berkumpul untuk berbagi pemikiran, komentar, dan ide (Bilgin, 2018). Felix, Rauschnabel, \& Hinsch (2016) Social Media Marketing adalah salah satu bentuk strategi pemasaran dengan menggunakan konsep jejaring atau media sosial. Social media marketing adalah penggunaan platform media sosial untuk memasarkan produk atau jasa yang ditawarkan suatu perusahaan. Dengan begitu perusahaan dapat menjangkau banyak konsumen di banyak tempat (Syahbani \& Widodo, 2017).

Menurut Christ Hauer terdapat $4 \mathrm{C}$ dalam penggunaan media sosial. Berikut adalah penjelasan mengenai indikator $4 \mathrm{C}$, yaitu: Konteks (Context), Komunikasi (Communication), Kolaborasi (Collaboration), Koneksi (Connection). Terdapat penelitiaan yang dilakukan oleh Rizka Imelda dan Erni Martini (2019) menjelaskan bahwa promosi media sosial (online) memberikan pengaruh yang signifikan terhadap keputusan pembelian karena membantu konsumen dalam mendapat informasi mengenai barang atau produk yang ditawarkan suatu perusahaan atau pembisnis (Syahbani \& Widodo, 2017).

Promosi merupakan salah satu strategi dari bauran pemasaran yang memiliki pengaruh yang baik terhadap suatu perusahaan (Kismono, 2012). Promosi seseorang mendapatkan informasi mengenai produk yang ditawarkan dan disajikan. Sehingga terpengaruhi dan tertarik untuk memiliki dan membeli produk tersebut. Pada era sekarang promosi bukan hanya dengan membagikan brosur, papan nama perusahaan, koran, radio, dan iklan televisi. Namun, perkembangan zaman yang membuat kegiatan promosi menjadi semakin mudah dengan adanya jaringan internet yang menghubungkan seseorang dengan yang lain (Daud, 2013).

\section{Word of Mouth (WOM)}

Word of Mouth (WOM) merupakan komunikasi yang sering digunakan untuk kepentingan internal dan eksternal suatu organisasi atau perusahaan. Word of Mouth (WOM) 
JoIE: Journal of Islamic Economics | Mufti Afif, Aulia Fathan Mubin, Ahmad Suminto P-ISSN: 2807-7377

E-ISSN: 2807-7091

lebih efektif untuk memperlancar proses pemasaran dan mampu memberikan keuntungan pada perusahaan. Komunikasi tersebut berawal dari informasi yang didapatkan oleh seseorang tentang suatu produk, baik dari media massa, dari interaksi sosial maupun dari pengalaman konsumsi, diteruskan kepada orang lain dan dalam proses itu informasi menyebar luas (Prasetiyo \& J.O.I Lhalauw, 2005).

Kotler dan Koller (2007) menyatakan bahwa komunikasi Word of Mouth (WOM) merupakan bentuk komunikasi berupa pemberian rekomendasi baik secara individu maupun kelompok terhadap suatu produk yang bertujuan memberikan informasi secara personal (Zainal, 2017) Mowen dan Minor (2002). menjelaskan Word of Mouth (WOM) adalah proses pertukaran pengalaman, pemikiran, komentar, atau ide-ide antara dua konsumen atau lebih, yang tak satupun merupakan sumber pemasaran (Yunita, 2012).

Menurut Hasan (2010) Word of Mouth (WOM) merupakan salah satu strategi promosi dalam kegiatan pemasaran yang menggunakan "orang ke orang” yang memiliki rasa puas untuk meningkatkan kesadaran tentang produk dan menghasilkan tingkat penjualan tertentu. Komunikasi dari mulut ke mulut dapat menyebar melalui jaringan bisnis, sosial dan masyarakat yang dianggap sangat berpengaruh. (Puspita, 2016) Menurut Budi Wiyono menjelaskan bahwa Word of Mouth (WOM) memiliki 4 indikator yaitu: membicarakan, mempromosikan, merekomendasikan, dan menjualkan (Robot, 2015).

Strategi pemasaran mulut ke mulut atau yang lebih Word of Mouth (WOM) salah satu strategi pemesaran yang dilakukan dengan menciptakan citra tentang produk barang maupun jasa yang baik suatu perusahaan. (Puspita, 2016) Sehingga konsumen yang merasakan kepuasan dan manfaat dari produk tersebut dapat merekomendasikan kepada orang lain dan mengakibatkan orang tersebut memutusakan untuk membeli barang yang ditawarkan. Hal tersebut tentunya dapat memberikan dampak yang baik bagi perusahaan untuk memasarkan produk serta jasa yang ditawarkan. Dalam strategi ini perusahaan pun tidak mengeluarkan biaya yang besar (Prasetiyo \& J.O.I Lhalauw, 2005). Hal tersebut dapat dilakukan dengan memberikan layanan serta kualitas barang yang baik sehingga konsumen menjadi puas dan mendapat keuntungan dari pembelian barang tersebut (Zainal, 2017).

Terdapat penelitiaan yang dilakukan oleh Muhammad Dian dan Evi Husniati Syaidah (2018), Iknesya Rahma Finanda dan Arjuna Wiwaha (2017); Sheng Chung Lo (2012); (Ulya, 2021), dari hasil penelitiannya disimpulkan bahwa strategi Word of Mouth (WOM) memberikan pengaruh positif terhadap keputusan pembelian karena pembeli mendapat 
JoIE: Journal of Islamic Economics | Mufti Afif, Aulia Fathan Mubin, Ahmad Suminto P-ISSN: 2807-7377

E-ISSN: 2807-7091

informasi dari orang yang memiliki pengalaman dan kesan baik terhadap perusahaan atau pembisnis sehingga mampu merekomendasikan kepada orang lain.

\section{METODE PENELITIAN}

\section{Jenis Penelitian}

Penelitian ini termasuk dalam jenis penelitian lapangan (field research), yaitu melakukan kegiatan di lapangan tertentu untuk memperoleh berbagai data dan informasi yang diperlukan (Sugiyono, 2020).

\section{Lokasi Penelitian}

Penelitian ini diadakan di Toko Buku La Tansa Gontor adalah salah satu unit usaha yang dimiliki oleh Pondok Modern Darussalam Gontor terletak di Kota Ponorogo, dan beralamat di Jalan Hos Cokroaminoto No. 66 Kabupaten Ponorogo, Provinsi Jawa Timur.

\section{Populasi dan Sampel}

Sampel yang digunakan dalam peneliatian ini adalah sebagian dari populasi jumlah konsumen Toko Buku La Tansa Gontor. Dalam penelitian ini ukuran sampel yang digunakan berjumlah 300 orang dengan jumlah populasi yang tidak terhitung. Menurut Nunnaly (1970) menyatakan bahwa ukuran responden pada uji coba adalah sebesar sepuluh kali lipat dari jumlah instrumen yang digunakan untuk alat ukur. Jika jumlah instrumen 30 butir maja memerlukan 300 responden untuk penelitian (Alwi, 2016).

\section{Teknik Pengambilan Sampel}

Teknik pengambilan sampel menggunakan sampel random sampling yaitu pengambilan anggota sampel dari populasi dilakukan secara acak tanpa memperhatikan setrata dalam populasi itu. Adapun skala pengukuran mengunakan skala likert. Skala pengukuran merupakan kesepakatan yang digunakan sebagai acuan untuk menentukan panjang pendeknya interval yang ada dalam alat ukur, sehingga menghasilkan data kuatitatif. Skala likert digunakan untuk mengukur sikap, pendapat, dan persepsi seseorang atau sekelompok seseorang orang tentang fenomena sosial (Sugiyono, 2020).

\section{Analisis Penelitian}

Metode analisis yang digunakan dalam tulisan ini adalah metode penelitian deskriptif kuantitatif yang bertujuan untuk menjelaskan mengenai pengaruh promosi media sosial (online) dan Word of Mouth (WOM) terhadap keputusan pembelian konsumen Toko Buku La Tansa Gontor serta dampak positif bagi pelaku usaha dan konsumen atau pelanggan. Adapun 
JoIE: Journal of Islamic Economics | Mufti Afif, Aulia Fathan Mubin, Ahmad Suminto P-ISSN: 2807-7377

E-ISSN: 2807-7091

data yang digunakan adalah data sekunder dan data primer, data sekunder yang diperoleh dari studi jurnal, buku-buku dan internet yang berkaitan dengan penelitian.

\section{HIPOTESIS DAN KERANGKA BERFIKIR PENELITIAN}

\section{Hipotesis Penelitian}

Hipotesis merupakan jawaban sementara terhadap rumusan masalah penelitian, dimana rumusan masalah penelitian telah dinyatakan dalam bentuk kalimat pertanyaan. Serta merupakan jawaban teoritis terhadap rumusan masalah dalam penelitian. Penelitian yang merumusakan hipotesis adalah penelitian yang menggunakan pendekatan kuantitatif. (Sugiyono, 2020)

1) Pengaruh Promosi Media Sosial terhadap Keputusan Pembelian Konsumen

$\mathrm{Ho}_{1}$ : Promosi media sosial (online) berpengaruh tidak signifikan terhadap keputusan pembelian konsumen Toko Buku La Tansa.

$\mathrm{Ha}_{1}$ : Promosi media sosial (online) (WOM) berpengaruh signifikan terhadap keputusan pembelian konsumen Toko Buku La Tansa.

2) Pengaruh Word of Mouth (WOM) terhadap Keputusan Pembelian Konsumen

$\mathrm{Ho}_{2}$ : Word of Mouth (WOM) berpengaruh tidak signifikan terhadap keputusan pembelian pelanggan Toko Buku La Tansa.

$\mathrm{Ha}_{2} \quad$ : Word of Mouth (WOM) berpengaruh signifikan terhadap keputusan pembelian Pelanggan Toko Buku La Tansa.

\section{Kerangka Penelitian}

Adapaun variabel independen dalam penelitian ini yaitu promosi media sosial (online) (X1) dan Word of Mouth (WOM) (X2). Sedangkan variabel dependen disebut sebagai variabel output, kriteria, atau konsekuen. variabel dependen atau variabel terkait adalah variabel yang dipengaruhi atau yang menjadi akibat, karena adanya variabel bebas. (Sugiyono, 2020) Adapun variabel dependen dalam penelitian ini yaitu keputusan pembelian konsumen (Y). Berikut adalah kerangka berfikir dalam penelitian ini: 


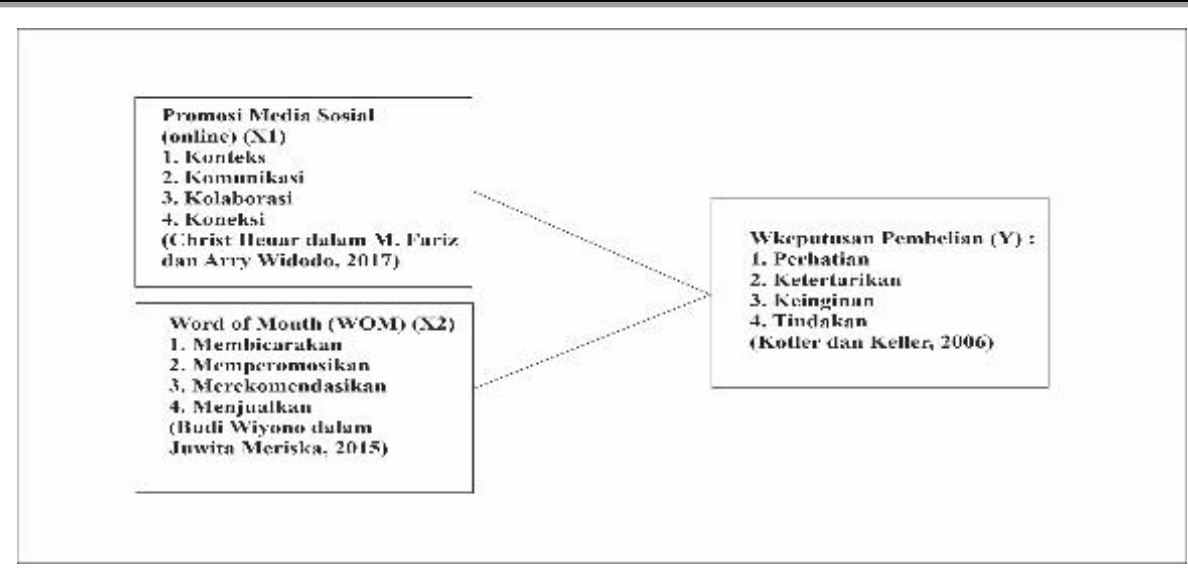

Gambar 1. Kerangka Pemikiran

\section{ANALISIS DAN PEMBAHASAN}

\section{Profil Responden}

\section{1) Jenis Kelamin Responden}

Adapun data mengenai jenis kelamin responden konsumen Toko Buku La Tansa Gontor sebagai berikut:

\section{Tabel 4.1. Jenis Kelamin Responden}

\begin{tabular}{ll|r|r|r|r}
\hline & & & & \multicolumn{2}{c}{$\begin{array}{c}\text { Cumulative } \\
\text { Percent }\end{array}$} \\
\hline Valid & Laki-laki & 267 & 89.0 & 89.0 & 89.0 \\
\cline { 2 - 6 } & Perempuan & 33 & 11.0 & 11.0 & 100.0 \\
\cline { 2 - 6 } & Total & 300 & 100.0 & 100.0 & \\
\hline
\end{tabular}

Sumber: Data oleh, 2021

Berdasarkan tabel diatas menunjukkan bahwa konsumen Toko Buku La Tansa Gontor berjenis kelamin laki-laki sebanyak 267 responden (89\%) sedangkan konsumen berjenis berjenis kelamin perempuan sebanyak 33 responden (11\%), maka dapat disimpulkan bahwa mayoritas responden Toko Buku La Tansa adalah berjenis kelamin laki-laki dengan presentase $89 \%$.

\section{2) Usia Responden}

Adapun data mengenai usia responden konsumen Toko Buku La Tansa Gontor adalah sebagai berikut: 
JoIE: Journal of Islamic Economics | Mufti Afif, Aulia Fathan Mubin, Ahmad Suminto P-ISSN: 2807-7377

E-ISSN: 2807-7091

Tabel 4.2. Umur Responden

\begin{tabular}{lrr|r|r|r}
\hline & & & & \multicolumn{2}{c}{$\begin{array}{c}\text { Cumulative } \\
\text { Percent }\end{array}$} \\
\hline Valid & Frequency & Percent & Valid Percent & 90.0 \\
\cline { 2 - 7 } & $15-25$ & 270 & 90.0 & 90.0 & 96.3 \\
\cline { 2 - 7 } & $26-35$ & 19 & 6.3 & 6.3 & 100.0 \\
\hline & $36-50$ & 11 & 3.7 & 3.7 & \\
\hline
\end{tabular}

Sumber: Data diolah, 2021.

Berdasarkan tabel di atas, responden yang memiliki usia 15-25 tahun sebanyak 270 responden (90 \%), untuk responden yang memiliki usia 26-35 tahun sebanyak 19 responden $(6,3 \%)$ serta responden yang memiliki usia 36-50 berjumlah 11 responden $(3,7$ $\%)$. Sehingga dapat disimpulkan bahwa konsumen Toko Buku La Tansa Gontor mayoritas berusia 15-25 tahun dengan jumlah presentase $90 \%$.

\section{3) Pendidikan Responden}

Adapun data mengenai pendidikan responden konsumen Toko Buku La Tansa Gontor adalah sebagai berikut:

Tabel 4.3. Pendidikan Responden

\begin{tabular}{llr|r|r|r}
\hline & & & & \multicolumn{2}{c}{$\begin{array}{c}\text { Cumulative } \\
\text { Percent }\end{array}$} \\
\hline Valid & Frequency & \multicolumn{1}{c|}{ Percent } & Valid Percent & 48.3 \\
\cline { 2 - 7 } & SMA & 145 & 48.3 & 48.3 & 96.3 \\
\cline { 2 - 6 } & S1 & 144 & 48.0 & 48.0 & 100.0 \\
\cline { 2 - 6 } & S2 & 11 & 3.7 & 3.7 & \\
\hline
\end{tabular}

Sumber: Data diolah, 2021.

Berdasarkan tabel di atas menunjukan bahwa konsumen Toko Buku La Tansa Gontor yang berpendidikan SMA sebanyak 145 responden (48,3 \%), untuk kosumen yang berpendidikan S1 sebanyak 144 reponden (48 \%), serta konsumen yang berpendidikan S2 berjumlah 11 responden $(3,7 \%)$. Maka dapat disimpulkan bahwa mayoritas responden konsumen Toko Buku La Tansa Gontor berpendidikan SMA dengan presentase 48,3 \%.

\section{4) Gambaran Jawaban Responden}

Kuesioner diberikan kepada 300 responden untuk menjawab pernyataan-pernyataan dari indikator setiap variabel. Serta pernyataan dalam kuesioner diukur menggunakan skala likert yaitu sangat setuju, setuju, netral, tidak setuju, dangat tidak setuju. Dijelaskan dalam penyajian data berikut: 
JoIE: Journal of Islamic Economics | Mufti Afif, Aulia Fathan Mubin, Ahmad Suminto

P-ISSN: 2807-7377

E-ISSN: 2807-7091

a. Promosi media sosial (online)

Tabel 4.4. Rekapitulasi Jawaban Responden (X1)

\begin{tabular}{|c|c|c|c|c|c|c|c|c|c|c|c|}
\hline \multirow[t]{2}{*}{ No } & \multirow[t]{2}{*}{ Item } & \multicolumn{2}{|c|}{ Sangat Setuju } & \multicolumn{2}{|c|}{ Setuju } & \multicolumn{2}{|c|}{ Netral } & \multicolumn{2}{|c|}{$\begin{array}{l}\text { Tidak } \\
\text { Setuju }\end{array}$} & \multicolumn{2}{|c|}{$\begin{array}{l}\text { Sangat } \\
\text { Tidak } \\
\text { Setuju }\end{array}$} \\
\hline & & $\mathrm{F}$ & $\%$ & $\mathrm{~F}$ & $\%$ & $\mathrm{~F}$ & $\%$ & $\mathrm{~F}$ & $\%$ & $\mathrm{~F}$ & $\%$ \\
\hline 1 & $\mathrm{X} 1.1$ & 130 & 43,3 & 131 & 43,7 & 31 & 10,3 & 4 & 1,3 & 4 & 1,3 \\
\hline 2 & $\mathrm{X} 1.2$ & 83 & 27,7 & 160 & 53,3 & 51 & 17,0 & 4 & 1,3 & 2 & 0,7 \\
\hline 3 & $\mathrm{X} 1.3$ & 74 & 24,4 & 150 & 50,0 & 71 & 23,7 & 3 & 1,0 & 2 & 0,7 \\
\hline 4 & $\mathrm{X} 1.4$ & 104 & 34,7 & 155 & 51,7 & 39 & 13,0 & 1 & 0,3 & 1 & 0,3 \\
\hline 5 & $\mathrm{X} 1.5$ & 120 & 40,0 & 162 & 54,0 & 16 & 5,3 & 0 & 0,0 & 2 & 0,7 \\
\hline 6 & $\mathrm{X} 1.6$ & 92 & 30,7 & 148 & 49,3 & 55 & 18,3 & 4 & 1,3 & 1 & 0,3 \\
\hline 7 & $\mathrm{X} 1.7$ & 85 & 28,3 & 163 & 54,3 & 47 & 15,7 & 3 & 1,0 & 2 & 0,7 \\
\hline 8 & $\mathrm{X} 1.8$ & 83 & 27,7 & 142 & 47,3 & 60 & 20,0 & 13 & 4,3 & 2 & 0,7 \\
\hline
\end{tabular}

Sumber: Data diolah, 2021.

Dari tabel 4.4. dapat diketahui bahwa responden menjawab seluruh pertanyaan yang diberikan peneliti dengan hasil rekapitulasi di atas item pernyataan tentang promosi media sosial (online) (X1).

\section{b. Word of Mouth (WOM)}

Tabel 4.5. Rekapitulasi Jawaban Responden (X2)

\begin{tabular}{cccccccccccc}
\hline \multirow{2}{*}{ No } & \multirow{2}{*}{ Item } & \multicolumn{2}{c}{$\begin{array}{l}\text { Sangat } \\
\text { Setuju }\end{array}$} & \multicolumn{2}{c}{ Setuju } & \multicolumn{2}{c}{ Netral } & \multicolumn{2}{c}{ Tidak Setuju } & \multicolumn{2}{c}{$\begin{array}{c}\text { Sangat Tidak } \\
\text { Setuju }\end{array}$} \\
\cline { 2 - 14 } & & F & $\%$ & F & $\%$ & F & $\%$ & F & $\%$ & F & $\%$ \\
\hline 1 & X2.1 & 92 & 30,7 & 169 & 56,3 & 32 & 10,7 & 5 & 1,7 & 2 & 0,7 \\
\hline 2 & X2.2 & 70 & 23,3 & 166 & 55,3 & 57 & 19,0 & 6 & 2,0 & 1 & 0,3 \\
\hline 3 & X2.3 & 95 & 31,7 & 131 & 43,7 & 61 & 20,3 & 11 & 3,7 & 2 & 0,7 \\
\hline 4 & X2.4 & 111 & 37,0 & 145 & 48,3 & 37 & 12,3 & 4 & 1,3 & 3 & 1,0 \\
\hline 5 & X2.5 & 90 & 30,0 & 138 & 46,0 & 64 & 21,3 & 6 & 2,0 & 2 & 0,7 \\
\hline 6 & X2.6 & 85 & 28,3 & 162 & 54,0 & 48 & 16,0 & 4 & 1,3 & 1 & 0,3 \\
\hline 7 & X2.7 & 107 & 35,7 & 133 & 44,3 & 58 & 18,0 & 3 & 1,0 & 3 & 1,0 \\
\hline 8 & X2.8 & 104 & 34,7 & 138 & 46,0 & 51 & 17,0 & 4 & 1,3 & 3 & 1,0 \\
\hline
\end{tabular}

Sumber: Data diolah, 2021.

Dari tabel 4.5. dapat diketahui bahwa responden menjawab seluruh pertanyaan yang diberikan peneliti dengan hasil rekapitulasi setiap item pernyataan tentang Word of Mouth (WOM) (X2).

c. Keputusan Pembelian

Tabel 4.6. Rekapitulasi Jawaban Responden (Y)

\begin{tabular}{|c|c|c|c|c|c|c|c|c|c|c|c|}
\hline \multirow[t]{2}{*}{ No } & \multirow[t]{2}{*}{ Item } & \multicolumn{2}{|c|}{ Sangat Setuju } & \multicolumn{2}{|c|}{ Setuju } & \multicolumn{2}{|c|}{ Netral } & \multicolumn{2}{|c|}{ Tidak Setuju } & \multicolumn{2}{|c|}{$\begin{array}{c}\text { Sangat Tidak } \\
\text { Setuju }\end{array}$} \\
\hline & & $\mathrm{F}$ & $\%$ & $\mathrm{~F}$ & $\%$ & $\mathrm{~F}$ & $\%$ & $\mathrm{~F}$ & $\%$ & $\mathrm{~F}$ & $\%$ \\
\hline 1 & Y1 & 96 & 32,0 & 134 & 44,7 & 64 & 21,3 & 4 & 1,3 & 2 & 0,7 \\
\hline 2 & Y2 & 122 & 40,7 & 149 & 49,7 & 26 & 8,7 & 1 & 0,3 & 2 & 0,7 \\
\hline 3 & Y3 & 127 & 42,3 & 142 & 47,3 & 30 & 10,0 & 0 & 0,0 & 1 & 0,3 \\
\hline 4 & Y4 & 132 & 44,0 & 131 & 43,7 & 33 & 11,0 & 2 & 0,7 & 2 & 0,7 \\
\hline
\end{tabular}

Sumber: Data diolah, 2021. 
JoIE: Journal of Islamic Economics | Mufti Afif, Aulia Fathan Mubin, Ahmad Suminto P-ISSN: 2807-7377

E-ISSN: 2807-7091

Dari tabel 4.5. dapat diketahui bahwa responden menjawab seluruh pertanyaan yang diberikan peneliti dengan hasil rekapitulasi setiap item pernyataan tentang keputusan pembelian (Y).

\section{Uji Instrumen Penelitian}

\section{1) Uji Validitas Instrumen}

Uji Validitas merupakan suatu ukuran yang menunjukan tingkat keandalan atau keabsahan suatu alat ukur. Validitas merupakan derajat ketepatan antara data yang terjadi pada objek penelitian dengan daya yang dapat dilaporkan oleh peneliti. Validitas digunakan untuk mengetahui kelayakan butir-butir dalam suatu daftar pertanyaan dalam mendifinisikan suatu variable. (Sugiyono, 2020) Uji validitas dilakukan dengan membandingkan nilai $r$ hitung dengan $r$ tabel untuk tingkat signifikansi 5 persen dari degree of freedom $(\mathrm{df})=\mathrm{n}-2$, dalam hal ini nilai $\mathrm{n}$ adalah jumlah sampel. Jika nilainya $>\mathrm{r}$ tabel maka pertanyaan atau indikator tersebut dinyatakan valid.

Instrumen penelitian ini di uji cobakan kepada 300 responden dengan hasil uji vaiditas sebagai berikut:

Tabel 4.7. Hasil Uji Validitas

\begin{tabular}{|c|c|c|c|c|}
\hline Variabel & Item & r-hitung & r-tabel & Kesimpulan \\
\hline \multirow{8}{*}{$\begin{array}{l}\text { Promosi } \\
\text { Media } \\
\text { Sosial (X1) }\end{array}$} & $\mathrm{X} 1.1$ & 0,673 & 0,113 & Valid \\
\hline & $\mathrm{X} 1.2$ & 0,719 & 0,113 & Valid \\
\hline & $\mathrm{X} 1.3$ & 0,717 & 0,113 & Valid \\
\hline & $\mathrm{X} 1.4$ & 0,714 & 0,113 & Valid \\
\hline & $\mathrm{X} 1.5$ & 0,670 & 0,113 & Valid \\
\hline & X1.6 & 0,709 & 0,113 & Valid \\
\hline & $\mathrm{X} 1.7$ & 0,688 & 0,113 & Valid \\
\hline & $\mathrm{X} 1.8$ & 0,693 & 0,113 & Valid \\
\hline \multirow{8}{*}{$\begin{array}{l}\text { Word of } \\
\text { Mouth (X2) }\end{array}$} & $\mathrm{X} 2.1$ & 0,603 & 0,113 & Valid \\
\hline & $\mathrm{X} 2.2$ & 0,752 & 0,113 & Valid \\
\hline & $\mathrm{X} 2.3$ & 0,788 & 0,113 & Valid \\
\hline & $\mathrm{X} 2.4$ & 0,746 & 0,113 & Valid \\
\hline & $\mathrm{X} 2.5$ & 0,685 & 0,113 & Valid \\
\hline & $\mathrm{X} 2.6$ & 0,772 & 0,113 & Valid \\
\hline & $\mathrm{X} 2.7$ & 0,765 & 0,113 & Valid \\
\hline & $\mathrm{X} 2.8$ & 0,762 & 0,113 & Valid \\
\hline \multirow{4}{*}{$\begin{array}{l}\text { Keputusan } \\
\text { Pembelian }\end{array}$} & $\mathrm{Y} 1$ & 0,712 & 0,113 & Valid \\
\hline & $\mathrm{Y} 2$ & 0,780 & 0,113 & Valid \\
\hline & Y3 & 0,700 & 0,113 & Valid \\
\hline & Y4 & 0,783 & 0,113 & Valid \\
\hline
\end{tabular}

Sumber: Data diolah, 2021.

Berdasarkan tabel di atas terlihat bahwa nilai $\mathrm{r}$ hitung seluruh item pernyataan variabel dalam penelitian ini lebih besar dari pada $r$ tabel 0,113 sehingga dapat disimpulkan kuisioner variabel promosi media sosial (online) (X1), Word of Mouth (WOM) (X2), dan keputusan pembelian (Y) dinyatakan valid. 
JoIE: Journal of Islamic Economics | Mufti Afif, Aulia Fathan Mubin, Ahmad Suminto

P-ISSN: 2807-7377

E-ISSN: 2807-7091

\section{2) Uji Reliabilitas}

Reliabilitas adalah jika instrument yang digunakan cukup dapat dipercaya untuk digunakan sebagai alat pengumpul data. Suatu objek dinyatakan reliabel apabila dua atau lebih peneliti dalam objek yang sama mengasilkan data yang sama dan bila dipecah menjadi dua menunjukkan data yang berbeda. Jika alat ukur yang digunakan stabil, baik, andal dan dapat digunakan untuk prediksi, maka alat ukur tersebut dianggap reliabel atau terpercaya. Penelitian menggunakan program SPSS dalam penelitian ini. jika nilai Alpha > 0,70 maka dapat dikatakan reliabel. (Arikunto, 2013) Peneliti menggunakan metode Cronbach's Alpha $(\alpha)$ dalam menguji reliabilitas kuesioner pada penelitian ini.

Tabel 4.8. Hasil Uji Reliabilitas

\begin{tabular}{llll}
\hline Variabel & $\begin{array}{l}\text { Cronbach } \\
\text { Alpha }\end{array}$ & Standard & Kesimpulan \\
\hline Promosi Media Sosial (X1) & 0,771 & 0,70 & Reliabel \\
\hline Word of Mouth (X2) & 0,779 & 0,70 & Reliabel \\
\hline Keputusan Pembelian (Y) & 0,795 & 0,70 & Reliabel
\end{tabular}

Sumber: Data diolah, 2021.

Berdasarkan tabel di atas terlihat bahwa niai cornbach alpha seluruh kuisioner variabel penelitian ini lebih besar dari 0,70 sehingga dapat disimpulkan kuisioner variabel promosi media sosial (online) (X1), Word of Mouth (WOM) (X2), dan Keputusan Pembelian (Y) dinyatakan reliabel.

\section{Uji Asumsi Klasik}

\section{1) Uji Normalitas}

Uji normalitas adalah untuk menguji apakah data berdistribusi normal sehingga dapat digunakan dalam statistik parametrik; jika data tidak berdistribusi normal maka dapat digunakan statistik non parametrik. (Sujarweni, 2015) Statistik parametrik mensyaratkan bahwa data setiap varibel akan dianalisis harus berdistribusi normal. Dengan mengevaluasi nilai signifikan ini, kita dapat menarik kesimpulan dan menentukan apakah datanya normal. Uji normalitas menggunakan teknik KolmogorovSmirnov Test. Dengan ketentuan jika nilai sig > 0,05 maka data dinyatakan berdistribusi normal. 
JoIE: Journal of Islamic Economics | Mufti Afif, Aulia Fathan Mubin, Ahmad Suminto

P-ISSN: 2807-7377

E-ISSN: 2807-7091

Tabel 4.9. Hasil Uji Normalitas

\begin{tabular}{llr}
\hline \multicolumn{2}{c}{ One-Sample Kolmogorov-Smirnov Test } \\
\hline & & \multicolumn{2}{c}{$\begin{array}{c}\text { Unstandardized } \\
\text { Residual }\end{array}$} \\
\hline $\mathrm{N}$ & & 300 \\
\hline Normal Parameters ${ }^{\mathrm{a}, \mathrm{b}}$ & Mean &, 0000000 \\
& Std. & 1,37777255 \\
& Deviation &, 047 \\
\hline \multirow{2}{*}{ Most Extreme Differences } & Absolute &, 024 \\
\cline { 2 - 3 } & Positive &,- 047 \\
\cline { 2 - 3 } & Negative &, 047 \\
\hline Test Statistic & &, $200^{\mathrm{c}, \mathrm{d}}$ \\
\hline Asymp. Sig. (2-tailed) & & \\
\hline
\end{tabular}

Berdasarkan tabel di atas dapat ditunjukkan bahwa hasil uji normalitas pada tabel one-sample Kolmogrov-Smirnov Test diperoleh nilai Asymp sig 0,200 lebih besar dari 0,05. Maka data dalam penelitian ini berdistribusi normal.

\section{2) Uji Multikolinieritas}

Uji multikolinieritas dilakukan untuk menguji apakah model regresi ditemukan adanya korelasi antar variable independen. Model regresi yang baik seharusnya tidak terjadi korelasi antara variable independen multikolineritas terdapat efek kombinasi dua atau lebih variable independen (Widarjono, 2010). Kesamaan antar variabel independen akan menghasilkan korelasi yang sangat kuat. Selain itu, pengujian menghindari kebiasaan menguji secara lokal pengaruh masing-masing variabel independen terhadap variabel dependen selama proses pengambilan keputusan. Pengujian multikolinearitas merupakan persyaratan untuk semua pengujian kausalitas Jika VIF yang dihasilkan diantara 1-10 maka tidak terjadi multikolinieritas (Gunawan, 2017).

Tabel 4.10. Uji Multikolinieritas

\begin{tabular}{|c|c|c|c|c|c|c|c|}
\hline \multirow[b]{2}{*}{ Model } & \multicolumn{2}{|c|}{$\begin{array}{l}\text { Unstandardized } \\
\text { Coefficients }\end{array}$} & \multicolumn{3}{|l|}{$\begin{array}{c}\text { Standardiz } \\
\text { ed } \\
\text { Coefficient } \\
\text { s }\end{array}$} & \multicolumn{2}{|c|}{$\begin{array}{l}\text { Collinearity } \\
\text { Statistics }\end{array}$} \\
\hline & B & $\begin{array}{l}\text { Std. } \\
\text { Error }\end{array}$ & Beta & $\mathrm{t}$ & $\begin{array}{l}\mathrm{Si} \\
\mathrm{g} .\end{array}$ & $\begin{array}{c}\text { Tolera } \\
\text { nce }\end{array}$ & $\begin{array}{l}\mathrm{VI} \\
\mathrm{F}\end{array}$ \\
\hline $1 \quad$ (Constant) & 3,571 & ,663 & & $\begin{array}{r}5 \\
38 \\
5 \\
\end{array}$ & $\begin{array}{r}0 \\
00\end{array}$ & & \\
\hline Promosi &, 154 & ,026 & ,297 & $\begin{array}{r}5 \\
86 \\
3 \\
\end{array}$ & $\begin{array}{r}, 0 \\
00\end{array}$ & ,528 & $\begin{array}{r}1,8 \\
92\end{array}$ \\
\hline $\begin{array}{l}\text { Word Of } \\
\text { Mouth }\end{array}$ &, 254 & ,024 &, 537 & $\begin{array}{r}10 \\
5 \\
79\end{array}$ & $\begin{array}{r}, 0 \\
00\end{array}$ &, 528 & $\begin{array}{r}1,8 \\
92\end{array}$ \\
\hline
\end{tabular}

a. Dependent Variable: Keputusan Pembelian 
JoIE: Journal of Islamic Economics | Mufti Afif, Aulia Fathan Mubin, Ahmad Suminto

P-ISSN: 2807-7377

E-ISSN: 2807-7091

Sumber: Data diolah, 2021

Berdasarkan tabel coefficients di atas menunjukkan kedua variabel nilai VIF promosi media sosial (online) sebesar 1,892, Word of Mouth (WOM) sebesar 1,892, atau kurang dari 10 maka tidak ada masalah multikolinieritas dalam penelitian ini.

\section{3) Uji Autokorelasi}

Autokorelasi bertujuan untuk mengetahui apakah terdapat korelasi tertentu antara variabel perancu dengan variabel sebelumnya dalam kurun waktu tertentu. Uji autokorelasi dalam penelitian ini menggunakan nilai Durbin Watson. Pengambilan keputusan dengan menentukan nilai $\alpha$ dengan dtabel $(\mathrm{n}, \mathrm{k})$ terdiri dari $\mathrm{dL}$ dan $\mathrm{dU}$ serta menetukan kriteria pengujian. (Sulianto, 2011)

Tabel 4.11. Uji Autokorelasi

\begin{tabular}{lc|r|r|r|r}
\hline $\begin{array}{c}\text { Mo } \\
\text { del }\end{array}$ & $\mathrm{R}$ & $\begin{array}{c}\mathrm{R} \\
\text { Square }\end{array}$ & $\begin{array}{c}\text { Adjusted R } \\
\text { Square }\end{array}$ & $\begin{array}{c}\text { Std. Error } \\
\text { of the } \\
\text { Estimate }\end{array}$ & $\begin{array}{c}\text { Durbin- } \\
\text { Watson }\end{array}$ \\
\hline 1 &, $090^{\mathrm{a}}$ &, 008 &, 005 & 2,15864 & 1,957 \\
\hline
\end{tabular}

a. Predictors: (Constant), Promosi Media Sosial, Word of Mouth

b. Dependent Variable: Keputusan Pembelian

Berdasarkan tabel di atas menunjukkan hasil uji autokorelasi dengan nilai $\mathrm{Dw}=$ 1,957 , kemudian mencari dU dan $\mathrm{dL}$ pada nilai $\mathrm{n}=300$ dan $\mathrm{k}=2$. Diperoleh nilai $\mathrm{dU}=$ $1,824, \mathrm{dW}=1,957$. Jadi $\mathrm{dU}<\mathrm{Dw}<(4-\mathrm{dU}) \Leftrightarrow 1,824<1,957<(4-1,824) \Leftrightarrow 1,824<$ $1,957<2,179$. Maka dapat disimpulkan bahwa penelitian ini tidak ada masalah autokorelasi.

\section{4) Uji Heteroskedastisitas}

Heteroskedastisitas berarti varian variabel dalam model tidak sama. pengujian ini memeriksa perbedaan varian sisa dari satu periode pengamatan ke periode pengamatan lainnya. Cara memprediksi ada tidaknya heterokedastisitias pada suatu model dapat diuji dengan uji Spearnan, apabila nilai signifikansi (Sig.) > 0,05 maka tidak terjadi gejala Heteroskedastisitas dan apabila nilai signifikansi (Sig.) $<0,05$ maka terjadi gejala Heteroskedastisitas. 
JoIE: Journal of Islamic Economics | Mufti Afif, Aulia Fathan Mubin, Ahmad Suminto P-ISSN: 2807-7377

E-ISSN: 2807-7091

Tabel 4.12. Uji Heteroskedastisitas

\begin{tabular}{|c|c|c|c|c|c|}
\hline & & & $\begin{array}{l}\text { Pro } \\
\text { mos } \\
\mathrm{i}\end{array}$ & $\begin{array}{l}\text { Word } \\
\text { Of } \\
\text { Mouth }\end{array}$ & $\begin{array}{l}\text { Unstandar } \\
\text { dized } \\
\text { Residual }\end{array}$ \\
\hline \multirow[t]{9}{*}{$\begin{array}{l}\text { Spearm } \\
\text { an's rho }\end{array}$} & \multirow[t]{3}{*}{ Promosi } & $\begin{array}{l}\text { Correlation } \\
\text { Coefficient }\end{array}$ & $\begin{array}{r}1.00 \\
0\end{array}$ & $.640^{* *}$ & -.045 \\
\hline & & Sig. (2-tailed) & . & .000 & .440 \\
\hline & & $\mathrm{N}$ & 300 & 300 & 300 \\
\hline & \multirow[t]{3}{*}{$\begin{array}{l}\text { Word Of } \\
\text { Mouth }\end{array}$} & $\begin{array}{l}\text { Correlation } \\
\text { Coefficient }\end{array}$ & $\begin{array}{r}640 \\
* * * \\
\end{array}$ & 1.000 & .009 \\
\hline & & Sig. (2-tailed) & .000 & . & .872 \\
\hline & & $\mathrm{N}$ & 300 & 300 & 300 \\
\hline & \multirow[t]{3}{*}{$\begin{array}{l}\text { Unstandardiz } \\
\text { ed Residual }\end{array}$} & $\begin{array}{l}\text { Correlation } \\
\text { Coefficient }\end{array}$ & .045 & .009 & 1.000 \\
\hline & & Sig. (2-tailed) & .440 & .872 & \\
\hline & & $\mathrm{N}$ & 300 & 300 & 300 \\
\hline
\end{tabular}

Berdasarkan tabel di atas menunjukkan bahwa nilai Sig variabel promosi media sosial (online) sebesar 0,440 dan nilai Sig variabel Word of Mouth (WOM) sebesar 0,872. Seluruh variabel dalam penelitian ini memiliki nilai Sig $>0,05$ sehingga dapat disimpulkan tidak terjadi heterokedastisitas.

\section{Uji Hipotesis}

\section{1) Uji Regresi Linier Berganda}

Analisis regresi ganda adalah regresi dimana variabel terikat dihubungkan dengan lebih dari satu variabel bebas namun masih menunjukkan hubungan yang linier. (Hasan I. , 2014) Analisis regresi linier berganda merupakan teknik analisis data yang sering digunakan dalam mengolah multivariabel. Analisis regresi digunakan untuk menguji kebenaran hipotesis dalam penelitian ini (Gunawan, 2017).

Tabel 4.13. Uji Analisis Regresi Linier Berganda

\begin{tabular}{|c|c|c|c|c|c|c|}
\hline \multirow[b]{2}{*}{ Model } & \multicolumn{3}{|r|}{$\begin{array}{l}\text { Standard } \\
\text { ized } \\
\text { Coeffici } \\
\text { ents }\end{array}$} & \multirow[b]{2}{*}{$\mathrm{t}$} & \multicolumn{2}{|c|}{$\begin{array}{c}\text { Collinearity } \\
\text { Statistics }\end{array}$} \\
\hline & B & $\begin{array}{l}\text { Std. } \\
\text { Error }\end{array}$ & Beta & & $\begin{array}{c}\text { Tole } \\
\text { ranc } \\
\mathrm{e}\end{array}$ & VIF \\
\hline (Constant) & 3,571 &, 663 & & 5,385 & & \\
\hline
\end{tabular}


JoIE: Journal of Islamic Economics | Mufti Afif, Aulia Fathan Mubin, Ahmad Suminto

P-ISSN: 2807-7377

E-ISSN: 2807-7091

\begin{tabular}{l|r|r|r|r|r|r|r}
\hline Promosi &, 154 &, 026 &, 297 & 5,863 &, 528 & 1,892 \\
\hline $\begin{array}{l}\text { Word Of } \\
\text { Mouth }\end{array}$ &, 254 &, 024 &, 537 & 10,579 &, 528 & 1,892 \\
\hline
\end{tabular}

a. Dependent Variable: Keputusan Pembelian

Data diolah, 2021.

Berdasarkan hasil analisis regresi di atas maka diperoleh model regresi berganda sebagai berikut:

$$
\mathrm{Y}=3,571+0,154+0,254+\mathrm{e}
$$

Berdasarkan model regresi di atas maka diperoleh model regresi berganda sebagai berikut:

1) Konstanta sebesar 3,571 artinya jika promosi media sosial (online) (X1) dan word of mouth nilainya adalah nol maka tingkat keputusan pembelian (Y) nilainya adalah 3,571 .

2) Nilai koefisien regresi variabel promosi media sosial (online) sebesar 0,154 atau 15,4 $\%$ artinya apabila pengaruh promosi media sosial (online) (X1) naik sebedar $1 \%$ maka keputusan pembelian (Y) akan naik sebesar 0,154 atau 15,4\%.

3) Nilai koefisien regresi variabel Word of Mouth (WOM) (X2) bernilai positif sebesar 0,254 atau 25,4\% naik sebesar $1 \%$ maka Word of Mouth (WOM) (X2) akan naik sebesar 0,254 atau $25,4 \%$.

\section{2) Uji Signifikan Simultan (Uji Statistik t)}

Uji $\mathrm{t}$ adalah pengujian koefisien parsial individual yang digunakan untuk mengetahui apakah variabel independen secara individual mempengaruhi variabel dependen. Koefisien korelasi parsial adalah indeks atau angka yang digunakan untuk mengukur keeratan hubungan antara dua variabel, jika variabel yang lain konstan, pada hubungan yang melibatkan lebih dari dua variabel (Hasan I. , 2014).

Tabel 4.14. Uji Analisis Signifikan Simultan (Uji Statistik t)

\begin{tabular}{|c|c|c|c|c|c|c|c|}
\hline \multirow[b]{2}{*}{ Model } & \multicolumn{2}{|c|}{$\begin{array}{l}\text { Unstandardized } \\
\text { Coefficients }\end{array}$} & $\begin{array}{l}\text { Standardi } \\
\text { zed } \\
\text { Coefficie } \\
\text { nts }\end{array}$ & & & \multicolumn{2}{|c|}{$\begin{array}{c}\text { Collinearity } \\
\text { Statistics }\end{array}$} \\
\hline & B & $\begin{array}{l}\text { Std. } \\
\text { Error }\end{array}$ & & $\mathrm{t}$ & Sig. & $\begin{array}{l}\text { Tolera } \\
\text { nce }\end{array}$ & VIF \\
\hline (Constant) & 3,571 & 663 & & 5,385 & ,000 & & \\
\hline
\end{tabular}


JoIE: Journal of Islamic Economics | Mufti Afif, Aulia Fathan Mubin, Ahmad Suminto

P-ISSN: 2807-7377

E-ISSN: 2807-7091

Promosi

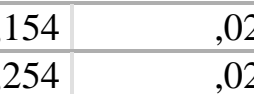

026

297

5,863

Dependent Variable: Keputusan Pembelian

Dari tabel diatas dapat diketahui nilai t dari setiap variabel adalah:

1) Uji hipotesis pengaruh promosi media sosial (online) $\left(\mathrm{X}_{1}\right)$ terhadap keputusan pembelian (Y).

Pada tabel di atas nilai signifikansi X1 lebih kecil dari (a) $0,05(0,000<0,05)$. Artinya $\mathrm{H}_{\mathrm{a}}$ diterima dan $\mathrm{H}_{0}$ ditolak. Jika dilihat dari nilai t hitung adalah 5,863 sedangkan nilai $\mathrm{t}$ tabel $1,967(\mathrm{df}=300-2-1=297)$ karena nilai $\mathrm{t}$ hitung $>\mathrm{t}$ tabel $(5,863>$ 1,967) dan taraf signifikan $0,000<0,05$ maka dapat disimpulkan bahwa promosi sosial media (online) berpengaruh positif dan signifikan terhadap keputusan pembelian.

2) Uji hipotesis pengaruh Word of Mouth (WOM) (X2) terhadap keputusan pembelian $(\mathrm{Y})$

Pada tabel diatas nilai signifikansi X2 lebih kecil dari (a) $0,05(0,000<0,05)$. Artinya $\mathrm{H}_{\mathrm{a}}$ diterima dan $\mathrm{H}_{0}$ ditolak. Jika dilihat dari nilai t hitung adalah 10,579 sedangkan nilai $\mathrm{t}$ tabel $1,967(\mathrm{df}=300-2-1=297)$ karena nilai $\mathrm{t}$ hitung $>\mathrm{t}$ tabel $(10,579$ $>1,967)$ dan taraf signifikan $0,000<0,05$ maka dapat disimpulkan bahwa Word of Mouth (WOM) berpengaruh positif dan signifikan terhadap keputusan pembelian.

\section{3) Uji Signifikan Parameter (Uji Statistik f)}

Uji ini digunakan untuk mengetahui apakah variabel independen secara bersamasama memiliki pengaruh yang signifikan terhadap variabel dependen. Atau mencari tahu apakah model regresi dapat digunakan untuk memprediksi variabel dependen. Yang penting ada relasi yang bisa diterapkan secara utuh (bisa digeneralisasikan). Dasar pengambilan keputusan adalah (Alghifari, 2003):

1) Jika $f_{\text {hitung }}>f_{\text {tabel}}$, maka $H_{0}$ ditolak $H_{a}$ diterima artinya variabel bebas secara bersamaan berpengaruh signifikan terhadap variabel terikat.

2) Jika $f_{\text {hitung }}<f_{\text {tabel}}$, maka $H_{0}$ diterima $H_{a}$ ditolak artinya variabel bebas secara bersamaan tidak berpengaruh signifikan terhadap variabel terikat (Alghifari, 2003).

Hasil pengujian F menggunakan SPSS sebagai berikut:

Tabel 4.15. Uji Signifikan Parameter (Uji f)

\begin{tabular}{lll|l|l|l}
\hline & Sum of & & Mean & & \\
Model & Squares & df & Square & F & Sig. \\
\hline
\end{tabular}


JoIE: Journal of Islamic Economics | Mufti Afif, Aulia Fathan Mubin, Ahmad Suminto P-ISSN: 2807-7377

E-ISSN: 2807-7091

\begin{tabular}{lll|r|r|r|r|}
\hline 1 & $\begin{array}{l}\text { Regressi } \\
\text { on }\end{array}$ & 837,018 & 2 & 418,509 & 218,9 &, $000^{\mathrm{b}}$ \\
& & & & 95 & \\
\cline { 2 - 7 } & Residual & 567,579 & 297 & 1,911 & & \\
\hline Total & 1404,597 & 299 & & & \\
\hline
\end{tabular}

a. Dependent Variable: Keputusan Pembelian

b. Predictors: (Constant), Word of Mouth, Promosi Sumber: data diolah, 2021.

Berdasarkan tabel di atas dari taraf signifikan (a) $0,05(0,000<0,05)$, jika dilihat dari nilai $\mathrm{F}$ hitung adalah sebesar 218,995 sedangkan nilai $\mathrm{F}$ tabel sebesar 3,02 (df=2;300 $-2-1=297)$. Karena $F$ hitung $>F$ tabel $(218,995>3,02)$ dan taraf signifikan $(0,000<$ 0,05) maka dapat disimpulkan bahwa promosi media sosial (online) dan Word of Mouth (WOM) bersama-sama berpengaruh positif dan signifikan terhadap keputusan pembelian. Sehingga $\mathrm{H}_{\mathrm{a}}$ diterima dan $\mathrm{H}_{0}$ ditolak.

\section{4) Uji Koefisien Determinasi (R2)}

Koefisien determinasi $\left(\mathrm{R}^{2}\right)$ digunakan untuk mengetahui prosentase perubahan variabel tidak bebas (Y) yang disebabkan oleh variabel bebas $(\mathrm{X})$. Jika $\mathrm{R}^{2}$ semakin besar, maka prosentase perubahan variabel tidak bebas (Y) yang disebabkan oleh variabel bebas (X) semakin tinggi. Jika $\mathrm{R}^{2}$ semakin kecil, maka presentase perubahan variabel tidak bebas yang disebabkan oleh variabel bebas semakin rendah (Sujarweni, 2015).

Tabel 4.16. Uji Signifikan Parameter (Uji f)

\begin{tabular}{rr|r|r|r}
\multicolumn{6}{c}{ Model Summary $^{\mathbf{b}}$} \\
\hline Model & R & R Square & $\begin{array}{c}\text { Adjusted R } \\
\text { Square }\end{array}$ & $\begin{array}{c}\text { Std. Error of } \\
\text { the Estimate }\end{array}$ \\
\hline & & & & \\
\hline 1 &, $772^{\mathrm{a}}$ &, 596 &, 593 & 1,38240 \\
\hline
\end{tabular}

a. Predictors: (Constant), Word Of Mouth, Promosi

b. Dependent Variable: Keputusan Pembelian Sumber: Data diolah, 2021.

Berdasarkan tabel di atas hasil koefisien determinasi pada tabel model summary di peroleh nilai $\mathrm{R}^{2}$ sebesar 0,596 atau 59,6\%. Sehingga presentase kontribusi promosi media sosial (online) dan word of mouth (WOM) terhadap keputusan pembelian sebesar $59,6 \%$. Sedangkan untuk sisanya 40,4\% dipengaruhi oleh variabel lainnya yang tidak dimasukkan dalam model penelitian ini.

\section{HASIL PEMBAHASAN}

\section{Pengaruh Media Sosial (online) terhadap Keputusan Pembelian}

Hasil uji hipotesis membuktikan bahwa promosi media sosial (online) berpengaruh terhadap keputusan pembelian. Jika dilihat dari nilai t hitung sebesar 5,863 sedangkan 
JoIE: Journal of Islamic Economics | Mufti Afif, Aulia Fathan Mubin, Ahmad Suminto P-ISSN: 2807-7377

E-ISSN: 2807-7091

nilai t tabel 1,967. Karena thitung $>\mathrm{t}$ tabel $(5,863>1,967)$. Dimana perhitungan secara parsial diperoleh dengan nilai signifikansinya adalah 0,000 pada taraf signifikansi $5 \%$ dimana nilai $0,000<0,05$ maka $\mathrm{H}_{0}$ ditolak dan $\mathrm{H}_{\mathrm{a}}$ diterima berarti promosi media sosial secara parsial berpengaruh terhadap keputusan pembelian. Jika dilihat dari koefisien regresi beta promosi media sosial mempunyai nilai 0,154 atau $15,4 \%$ yang berarti bahwa promosi media sosial mempengaruhi keputusan pembelian sebesar 15,4\%.

Dalam hal ini Toko Buku La Tansa Gontor menggunakan media sosial sebagai promosi karena sangat efektif dan efisien. Sehingga dapat memengaruhi keputusan pembelian konsumen Toko Buku La Tansa Gontor. Diterimanya hipotesis pertama ini menunjukan bahwa keputusan pembelian konsumen suatu perusahaan salah satunya dipengaruhi oleh promosi media sosial (online). Hasil penelitian ini relevan dengan penelitian yang dilakukan oleh Rizka Imelda dan Erni Martini (2019) hasil penelitian mereka menjelaskan bahwa promosi media sosial (online) memberikan pengaruh yang signifikan terhadap keputusan pembelian karena membantu konsumen dalam mendapat informasi mengenai barang atau produk yang ditawarkan suatu perusahaan atau pembisnis.

\section{Pengaruh Word of Mouth (WOM) terhadap Keputusan Pembelian}

Hasil uji hipotesis membuktikan bahwa Word of Mouth (WOM) berpengaruh terhadap keputusan pembelian. Jika dilihat dari nilai t hitung sebesar 10,579 sedangkan nilai $\mathrm{t}$ tabel 1,967 . Karena $\mathrm{t}$ hitung $>\mathrm{t}$ tabel $(10,579>1,967)$. Dimana perhitungan secara parsial diperoleh dengan nilai signifikansinya adalah 0,000 pada taraf signifikansi $5 \%$ dimana nilai $0,000<0,05$ maka $\mathrm{H}_{0}$ ditolak dan $\mathrm{H}_{\mathrm{a}}$ diterima berarti Word of Mouth (WOM) secara parsial berpengaruh terhadap keputusan pembelian. Jika dilihat dari koefisien regresi beta Word of Mouth (WOM) mempunyai nilai 0,254 atau 25,4\% yang berarti bahwa Word of Mouth (WOM) mempengaruhi keputusan pembelian sebesar 25,4 $\%$.

Dalam hal ini Toko Buku La Tansa Gontor menggunakan Word of Mouth (WOM) sebagai pemasaran karena sangat efektif dan efisien.hal tersebut mempengaruhi konsumen dalam melakukan keputusan pembelian. Diterimanya hipotesis kedua ini menunjukan bahwa keputusan pembelian konsumen suatu perusahaan salah satunya dipengaruhi oleh Word of Mouth (WOM). Hasil penelitian ini relevan dengan penelitian yang dilakukuan oleh Muhammad Dian dan Evi Husniati Syaidah (2018), Dari hasil penelitiannya disimpulkan bahwa strategi Word of Mouth (WOM) memberikan pengaruh 
JoIE: Journal of Islamic Economics | Mufti Afif, Aulia Fathan Mubin, Ahmad Suminto P-ISSN: 2807-7377

E-ISSN: 2807-7091

positif terhadap keputusan pembelian karena pembeli mendapat informasi dari orang yang memiliki pengalaman dan kesan baik terhadap perusahaan atau pembisnis sehingga mampu merekomendasikan kepada orang lain.

\section{KESIMPULAN}

Promosi media sosial (online) berpengaruh positif dan signifikan terhadap keputusan pembelian konsumen Toko Buku La Tansa Gontor, hal ini disebabkan karena admin media sosial Toko Buku La Tansa Gontor memberikan informasi yang baik dan menarik serta komunikasi yang responsif sehingga dapat mempengaruhi konsumen untuk melakukan keputusan pembelian terhadap barang yang disediakan dan tawarkan. Dan juga Word of Mouth (WOM) berpengaruh positif dan signifikan terhadap keputusan pembelian, hal tersebut disebabkan karena layanan yang berikan Toko Buku La Tansa Gontor memuaskan dan kesediaan barang yang dibutuh oleh konsumen cukup lengkap yang membuat konsumen merasa puas dan dilayani dengan baik sehingga hal tersebut berdampak timbulnya Word of Mouth (WOM) yang positif dan mengakibatkan konsumen terpengaruhi untuk melakukan keputusan pembelian barang yang disediakan dan ditawarkan. Untuk penelitian selanjutnya agar bisa mengembangkan variabel penelitian ini, karena masih ada faktor lain yang mempengaruhi keputusan beli konsumen seperti; kualitas pelayanan, kualitas prodik, harga dan sebagainya. Selain itu penelitian ini tidak mencerminkan perilaku konsumen secara umum, karena perbedaan jenis usaha juga dapat mempengaruhi perilaku konsumen.

\section{REFERENSI}

Alghifari. (2003). Statistika Indukatif Untuk Ekonomi dan Bisnis. Yogyakarta: AMP YKN.

Alwi, I. (2016). Kriteria Empirik Dalam Menentukan Ukuran Sampel pada Pengujian Hipotesis Stastika dan Analisis Butir. Jurnal Formatif.

Arikunto, S. (2013). Prosedur Penelitian Suatu pendekatan Praktik. Jakarta: Rineka Cipta.

Asnawi, N. (2017). Pemasaran Syariah: Teori, Filosofi dan Isu-Isu Kontenporer,. Depok: PT. Raja Grafindo Press.

Bilgin, Y. (2018). The Effect of Social Media Marketing on Brand Awareness, Brand Image, and Brand Loyalty. Business \& Management Studies: International Journal.

Daud, D. (2013). Pengaruh Promosi dan Kualitas Pengaruhnya terhadap Keputusan Konsumen Menggunkan Jasa Pembiayaan pada PT. Bess Finance Manado. Jurnal EMBA, 59-74. 
JoIE: Journal of Islamic Economics | Mufti Afif, Aulia Fathan Mubin, Ahmad Suminto P-ISSN: 2807-7377

E-ISSN: 2807-7091

Endang, I. (2013). Analisis Keputusan Pembelian Konsumen Melalui Media Online (EMarketing). Jurnal Ekonomi, 34-56.

Gunawan, I. (2017). Pengantar Statistika Inferesial. Jakarta : Rajawali Perss.

Hasan, A. (2010). Marketing dari Mulut Ke Mulut. Jakarta: Med Press.

Hasan, I. (2014). Pokok-pokok Metari Stastistik 1. Jakarta: Bumi Aksara.

Kismono, G. (2012). Bisnis Pengantar Edisi 2. Yogyakarta : BPFE.

Kotler, P. (2006). Manajemen Pemasaran Edisi Milenium Alih Bahasa Nebyamin Molan. Jakarta: Prenhallindo.

Prasetiyo, R., \& J.O.I Lhalauw, J. (2005). Perilaku Konsumen. Yogyakarta : Andi Offset .

Puspita, F. (2016). Pengaruh Harga, Citra Produk, dan Word of Mouth terhadap Keputusan Pembelian Konsumen. Jurnal Ilmu dan Riset Manajemen, 78-92.

Robot, J. M. (2015). Analisis Pengaruh Advertising, Personal Selling, Sales Promotion, Publicity dan Word of mouth terhadap Keputusan Pembelian. Jurnal Riset Bisnis dan Manajemen.

Schiffman , \& Prase, R. K. (2005). Perilaku Konsumen. Yogyakarta: Andi Offset .

Schiffman, L. G., \& Kanuk. (Jakarta). Perilaku Konsumen Alih bahasa Zulkifli Kasip. 2009, PT. Indeks Group Gramedia.

Siregar, S. (2017). Statistik Parametrik untuk Penelitian Kuantitatif. Jakarta: Bumi Aksara.

Sugiyono. (2020). Metode Penelitian Kuantitatif, Kualitatif dan R\&D. Bandung: Alfabet.

Sujarweni, V. W. (2015). SPSS Untuk Penelitian. Yogyakarta: Pustaka Baru Perss.

Sulianto. (2011). Ekonometrika Terapan Teori \& Aplikasi Dengan SPSS . Yogyakarta: Ani Publisher.

Swastha, B., \& Handoko, H. (2016). Manajemen Pemasaran (Analisis Perilaku Konsumen). Yogyakarta: BPFE.

Syahbani, M. F., \& Widodo, A. (2017). Food Blogger Istagram: Promotion Through Social Media. Jurnal Ecodemica.

Udin, M. M. (2020). Pengaruh Dimensi social media marketing melalui Instagram Terhadap Keputusan Pembelian Sayur Organik Merbabu (SOM). Jurnal Ekonomi Pertanian dan Agribisnis, 45.

Ulya, H. N. M. (2021). Pemulihan Perekonomian Jawa Timur di Masa Pandemi Covid-19 Melalui Sistem Pertanian Terpadu (SPT) Budikdamber (Budidaya Ikan dalam Ember). JoIE: Journal of Islamic Economics, 1(1).

Widarjono, A. (2010). Analisis Statistik multivaarian Terapan. Yogyakarta:: Unit Penerbit dan Percetakan Sekolah Tinggi Ilmu Manajemen YKPN, 2010. 
JoIE: Journal of Islamic Economics | Mufti Afif, Aulia Fathan Mubin, Ahmad Suminto P-ISSN: 2807-7377

E-ISSN: 2807-7091

Yuliansyah, H. (2017). Pengaruh Strategi Pemasaran Online (Online Marketing Strategy) terhadap Minat Beli Konsumen. Jurnal Pemasaran Kompetitif Manajemen Pemasaran.

Yunita. (2012). Pengaruh Word of Mouth, Iklan dan Atribut Produk terhadap Keputusan Pembelian dan Loyalitas Konsumen. Jurnal Manajemen Teknologi.

Zainal, V. R. (2017). Islamic Marketing Management. Jakarta: Bumi Aksara . 